\title{
The Organisation of Educational Space in the New Ukrainian School
}

\author{
Nadiia V. Bilousova ${ }^{\#, *}$, Tetiana V. Hordiienko", Nataliia M. Demchenko", \\ Olena S. Filonenko"\# and Artur A. Bobro"\#
}

\author{
Department of Pedagogics, Primary Education and Educational Management, Nizhyn Mykola Gogol State \\ University, Nizhyn, Ukraine
}

\begin{abstract}
Objective: The paper covers the issue of organisation of educational space of primary education in the conditions of establishment of the NUS. The purpose of the study was to determine the specific features in the organisation of educational space in foreign educational institutions and to provide recommendations for the organisation of educational space of the NUS.

Background: The school begins with the organisation of new educational space as a carrier of symbolic information, which ensures additional opportunities for the cognitive, aesthetic, ethical development of the subjects of the educational process. The ideas of organising the educational space of foreign countries, with a clear division into the physical environment, curriculum, human factors, are embodied in the practice of the New Ukrainian School (NUS) to organise opportunities to meet the needs of the educational process while having its own features.

Method: The authors used communicative, cognitive, transformative, systematising and control methods of teaching during the research.

Results: The concept of "educational space" is described; models of organisation of educational space are presented. The paper provides the analysis of an array of works of scholars, which cover various aspects of the definition of educational space. The educational sources, which are determined by the Methodical recommendations on the organisation of the educational space of the New Ukrainian School, are analysed.

Conclusion: Recommendations are given to future primary school teachers on the organisation of educational space and educational sources in classrooms of modern primary school. The general conclusions concerning the investigated problem are formulated.
\end{abstract}

Keywords: Specialised education, schoolchild, training, modern tendencies, foreign experience.

\section{INTRODUCTION}

At present, Ukraine is on the path of significant changes in the organisation of the educational space. Improving and updating the educational system involves the implementation of the Concept of the New Ukrainian School, which provides for a new organisation of the educational space of the primary school because the school plays an extraordinary role in the child becoming a creative, decent, welldeveloped, and thinking person. Thus, the physical space that accompanies the educational process constitutes a set of conditions that affect and form the cognitive abilities of primary school children, aesthetic and moral interests of children. The basis for creating an ergonomic and motivating educational space is the assessment of its material embodiment, as well as the perception of its educational atmosphere with educational impact. Of particular relevance is the creation of special conditions for students with mental

\footnotetext{
*Address correspondence to this author at the Department of Pedagogics, Primary Education and Educational Management, Nizhyn Mykola Gogol State University, Nizhyn, Ukraine; Tel: +380463123588;

E-mail: bilousova5883@tanu.pro

"These authors are equally contributed.
}

retardation, as this is the largest group of students with disabilities. At the same time, in some cases, with the correct creation of special educational conditions, mental retardation can be successfully adjusted.

Special educational needs of children of different categories vary in terms of specifics of health disabilities, which determines the special logic of the educational process. There are special educational needs inherent in all students with disabilities. First, it is the provision of early detection of abnormalities in the development of the child with subsequent specially organised training; secondly, changes in the content of curricula; third, the use of special methods, techniques and teaching aids, including specialised computer technology that takes special educational needs into consideration; fourth, individualisation of learning; fifth, provision of a special spatial and temporal organisation of the educational environment; sixth, the maximum expansion of educational space (going beyond the educational institution to expand the scope of life competence).

Studies of the educational space based on the ideas of "developmental learning" were theoretically and practically embodied in the articles of D. Elkonin 
and V. Davydov, as well as A. Asmolov, F. Mikhailov, V. Lazariev, V. Rubtsov, V. Riepkin, V. Slobodchykov, and others. New terms "space pedagogy" and "design in education" are introduced into pedagogical science and practice. Problems of educational space are actively researched by foreign and Ukrainian scholars, such as: E. Bachynska, E. Zeier, V. Lebedieva, O. Leonova, I. Meshkova, S. Podmazin, V. Rubtsov, O. Skidin, I. Ulanovska, O. Khmelnytska, I. Shendryk, H. Shedrovytsky and others.

The purpose of the study is to determine the features of the organisation of educational space in foreign educational institutions for children with mental retardation and to provide recommendations for the organisation of educational space of the NUS. To this end, the authors propose the implementation of the following objectives:

1. Consider possible approaches to the definition of "educational space" based on the analysis of scientific sources.

2. Analyse the experience of foreign countries in the organisation of educational space.

3. Identify modern requirements for the organisation of educational space, based on the experience of foreign countries.

4. Outline ways to organise the educational space of the modern Ukrainian school through the establishment of its educational sources.

\section{MATERIALS AND METHODS}

Most researchers consider the concept of "educational space" as a certain territory in education, within which the normalised educational activities are performed; a unity, an integral formation in education, which has its limits - world or European educational space, the educational space of the region, school, classroom, etc. Inclusive education involves adapting the education system to the needs of children with mental retardation. The special educational needs of such children determine the construction of the educational process, its structure and content. Getting an education in conditions of the inclusive environment means that such a student gets an education that is comparable to the final level of education of healthy peers and in the same calendar period. The child fully masters the basic curriculum and after graduation can receive the same document of education as its healthy peers. The main task is to create special conditions of educational space in the general education organisation, under which a child with mental retardation can exercise its right to education.

Ecological-personal model of educational space is widely represented in the articles of $\mathrm{V}$. Yasvin, who defines it as a system of influences and conditions of personality formation according to the given model, as well as opportunities for its development in the social and spatial environment [1]. Anthropologicalpsychological model of educational space is proposed in the articles of $V$. Slobodchikov. The educational space begins where those who teach and learn meet; where they together begin to design and build it. According to $V$. Slobodchikov, objectively, the educational environment can be described by two indicators: saturation and structure [2]. At the heart of the communicative-oriented model of educational space lies the unity of the teacher and the learner, i.e. the social environment of communicative interaction. The starting point for this approach to educational space is the understanding that a necessary condition for the development of the child is its participation in joint activities with an adult. Psychodidactic model of educational space (V. Davydov, V. Lebedeva, V. Orlov) is based on the idea of recognition for each student as a subject of the educational process, the priority of its individuality, personal experience [3]. According to the ecopsychological model of educational space, it is a system of psychological and pedagogical conditions and influences that create opportunities for the disclosure of interests and abilities of each individual, considering its natural potential and age capabilities.

Thus, the educational space is a system of influences and conditions that is to form the personality of a junior student, as well as opportunities for its development, contained in its social and spatialobjective environment [4]. According to A. Tsymbalar, "as a form of existence of objective reality, space expresses the relations between existing objects, determines the order of their location, density, plane, structure and describes all forms and trajectories of matter" $[5,6]$.

Educational space is defined as one that provides opportunities to form of "the spiritual face of a person, which is formed under the influence of moral and spiritual values, which is the property of its cultural circle, as well as the process of education, selfeducation, influence, polishing, the process of shaping the person's face". The regional educational space, the educational space of the city, the educational space of 
the school, and finally, the educational space of the individual are interpreted in scientific articles as special pedagogical phenomena [7].

The structure of the educational space includes three basic components:

- $\quad$ spatial-objective - spatial-objective conditions and opportunities for training, education, and socialisation of students;

- social - the space of conditions and opportunities that are created in interpersonal interaction between the subjects of the educational process (students, teachers, administration, parents, psychologists, etc.);

- psychodidactic - a set of educational technologies (content and methods of teaching and education), built on various psychological and didactic grounds [8].

According to our research, modern premises of Ukrainian schools are monotonous, not functional, not adapted to the rapid change of spatial location of students with mental retardation, have no recreation areas, classes in cities are overloaded with a large number of students (36 students), and therefore do not promote development either of independence and activity or creative thinking and creative abilities. They do not facilitate the fashioning of aesthetic tastes and, most importantly, the desire to learn. Therefore, the situation needs to change radically.

The main methods of teaching children with mental retardation at school, depending on the method of organising educational activities include the following:

1. Communicative method of teaching. The educational purpose of the lesson: mastering ready-made knowledge. Activities: a) teacher's presentation of new material, including problembased presentation, and students' perception of it; b) conversation on the content of new educational material, including heuristic or problem-searching; c) work with the text of the textbook, including the independent study of the text by students; d) evaluation of work.

2. Cognitive method of teaching. Educational purpose: perception, comprehension, and memorisation of new material by students. Students' activities: observation, modelling, a study of illustrations, perception, analysis, and generalisation of the demonstrated materials.
3. Transformative method of teaching. Didactic purpose: mastering by students and creative application of abilities and skills. Activities of teachers and students: performance of exercises, problem tasks, cognitive tasks, practical and production activities.

4. Systematising method of teaching. Didactic goal: generalisation and systematisation of knowledge, skills, and abilities. Activities: a) summarising the teacher's knowledge of several interrelated sections of the curriculum, b) summary conversation; compilation of systematic tables, etc.

5. Control method of teaching. Didactic goal: identification of the quality of learning, skills, and their correction. Activity: a performance by students of control written works, control oral questioning of students, the performance of practical tasks on the task of the teacher.

\section{RESULTS}

Special educational needs of students with mental retardation require the creation of specific material and technical support for their learning, ensuring the correctional and developmental orientation of the educational process, including the purposeful development of social competencies of students. Below, the authors analyse the organisation of inclusive education abroad.

Norway has an interesting experience of joint organisation of educational environment for children with mental retardation. One large room is divided by a partition into three parts: two separate classrooms with comfortable desks and a common area with a library, video library, additional materials. As in the NUS, the classroom has open cabinets with shelves, which store handouts and visual aids, books for everyday reading. Everything is arranged so that the child can come up and take the thing it needs. In our opinion, Norwegian schools of inclusive education have an interesting experience of conducting joint lessons-lectures for two classes, when the partition separating the premises is removed. Ukrainian schools can be advised to adapt the school assembly hall or recreation area to such a lecture audience. Authors believe that some of the material can be presented in the form of a lecture, even in primary school, thus allocating additional time to solve practical problems [9]. 
The majesty of open space design of school interior in Denmark attracts with its majesty. For example, in the specialised gymnasium Orestad in Copenhagen, space is divided into four levels by means of "rotary shutters". The levels are connected by a giant spiral staircase. There are no classes with four walls in their usual meaning. Space includes places for study and relaxation. Bright pillows add comfort. The ceiling in the form of a starry sky leads children to think that there are many unsolved mysteries of the universe. A feature of the organisation of such a room is wireless Internet. In the gymnasium, group learning is preferred [10-12].

Almost all primary schools for children with mental retardation in Belgium are computerised and arranged in the form of playrooms. The school has gyms and swimming pools. Starting from primary school, students are involved in the form of education that is innovative for Ukraine - online learning. Online classes for students are held for the entire class, and there is an individual form. It is interesting that some subjects are taught by specialists from Ukraine. The primary school is divided into interest centres, which are attended by groups. The school practices active communication through the implementation of various projects. The means of learning are nature, objects of school life, family, and society. Students have access to school and municipal libraries. An interesting form of work, in our opinion, is the creation of a school journal "Courier" by students. Both junior and senior students are members of the editorial board, who independently prepare materials, print and brochure magazine issues. At the same time, the presence of knowledge, the ability to fantasise, a sense of humour, etc. are valued $[13,14]$.

Much attention in the privileged institutions of England is paid to the comprehensive development of children with mental retardation. Children in schools not only learn: they play football, rugby, cricket, chess, do dozens of other sports, put on performances and scientific experiments, compete with other schools in the art of rhetoric and help the elderly. There are no permanent classes in English high school. According to the school curriculum, upon reaching the age of 14 , children decide for themselves what to learn. There are only three compulsory subjects: English, mathematics, and "science" - a course that combines the basic elements of biology, physics, and chemistry. In another - complete freedom of choice. Instead of attending the same lessons with the same class, English students appear in a new company at each lesson. There is no position of a class teacher. Each student has a mentor
- a teacher who monitors their progress in education, sports, and other areas of school life. In this case, the mentor may not teach their mentee any classes at all.

British inclusive education has always placed a strong emphasis on students' independent work, their ability to self-study and their ability to acquire knowledge without the help of a teacher. Girls and boys can communicate mainly on breaks, discos, and in special guest halls, which are in every home. It is not allowed to hold hands. And even more so, visit each other's bedrooms. Apart from the bar and disco, the school has other opportunities to enjoy. Students themselves organise clubs, such as chess, fishing, rhetoric, or science fiction. Schools have powerful libraries. Patrick Scheinin, dean of the Faculty of Education, says that the Finns have copied the model of secondary schools in Sweden, in which teachers are given the place of the driving force of education, they are the elite of the nation.

Inclusive education has become part of the national character. In Finland, all schools for children with mental retardation are almost the same: there are no elite, paid, special schools, etc. The children go to school in the morning and return in the evening. Educational services, food, textbooks, various technical support are free. Starting from the 7th grade, each student has their own laptop, which is stored in a special closet at the school [15]. Currently, Finland plans to rebuild all its schools with the use of the "open space" method - creating an open, flexible space for learning. This design of educational institutions is gaining popularity in many countries [16]. For example, a school may include three floors connected by a staircase. The "heart" of the school is a large hall on the ground floor, which is used as a dining room and a place for festive events. Students of all ages gather there. On each floor, there are halls, along the contour of which are placed classrooms, windows on the entire wall of which overlook the hall. It is very convenient and facilitates control over children. There are several recreation areas. There are also subject areas: classes in drawing, physics, chemistry, home economics, needlework (it is interesting that in such classes both boys and girls work together, performing both "boyish" and "girlish" work [17]. The only problem with such a design is noise. Therefore, upholstered furniture is used: sofas, armchairs, as well as movable screens, walls. This way, one can create a quiet place to work. Any student can choose not only a place (chair, sofa, "cave") in a large space but also a topic that they want to study at the moment [16]. 
Each school has classes for children with minor disabilities. In general, the main place in schools is given to the child, its needs, and interests. Much attention is paid to teamwork. Schools promote a healthy lifestyle, hence many physical education lessons. The creativity of students with mental retardation is developed as they are involved in art [17]. Now that Finland's experience is being followed by other countries, including Ukraine, it is important that they master the system of "openness", given its flexibility [16]. Speaking at a press conference for teachers in Belarus, Kari Louhivuora, a Finnish education expert, stressed that the secret of Finnish inclusive education is to create short days of study, have plenty of breaks and playtime during the day; a small amount of homework and a long vacation. All schools in the country study according to one curriculum. An important module of the system is to combine several subjects together: art and history; chemistry, industrial arts, foreign language; ICT, drawing, career education. But this does not happen all the time, but only a few weeks a year, when teachers come together to conduct joint classes. In the warm season, Finns hold classes in the open air, in the schoolyard, sitting on green grass or on benches made in the form of an amphitheatre. Thus, another zone is added. Authors would like to call it a "health zone". A very valuable fact is the presence of a mobile library. Special buses (currently about 200 of them), called bibliobuses, deliver books during the day to schools and kindergartens, and in the evening stop in residential areas of cities and villages [17].

The term "flexible class" is widely used in educational institutions for children with mental retardation in the United States. This room has mobile furniture-transformers, sofas, cabinets. The class is divided into seven zones: a zone of discoveries, news, a zone of materials, community, teachers, silence, and a theme-based zone. In the area of discoveries are objects that generate imagination. These are materials for decorative and applied arts, cameras, music, and recording devices, puzzles, books, magazines, etc. The news area resembles the Ukrainian educational source "Morning Meetings". This area houses the nature calendar, news of the day, information about school holidays, world and local news, goals for the day and homework. The material area stores pencils, pens, markers, sharpeners, staplers, scissors, eyelet punchers, rulers, paper, glue, tape, paper clips, napkins, paper towels, hand sanitiser, trash cans, and general-purpose tools. It is also recommended to use this place to place reference materials, such as guidebooks, textbooks, magazines, formulas, and vocabulary words. It can be a centre for classwork or homework, as well as for storing work or a portfolio.

The community area should gather students for the meeting. This is where something is planned, clarified, amended, debated, etc. In the zone of silence, students can seclude themselves from others and learn something, read it or dwell on their thoughts in a comfortable place. Teachers advise using headphones in this area. This area resembles the "Cave" area in Swiss schools. Teacher's area - parents, colleagues, and the administration should immediately understand who they are dealing with, so in this area, students' photos, gifts from former students should be placed. For some reason, the presence of such things is not always reflected in Ukrainian schools. The teacher should have either a desk, a few chairs, or a closet where they can put personal belongings, certificates, books, reference books, tests, records. In the themebased area, cabinets-transformers, devices, tables, a wall of words, cards are usually placed. If the room is small, Americans advise installing this area in a closet, on a shelf, a small table, a bulletin board, etc. [18]. An interesting idea came from the designers of Concord School (USA). There, they transformed the library into a creative multifunctional corridor that can be used both during classes and during recreation. They also added a hall for watching movies, cartoons, etc.

Thus, authors trace the clear tendency of Western inclusive education institutions regarding the requirements for the organisation of educational environment for children with mental retardation in such a way as to: provide more space for group and individual learning, communication, creativity: "get rid of the walls" with modern creative "open space" interior design; make the room have an aesthetically pleasing appearance not only on the inside but also on the outside; make the room multifunctional, bright, attractive, cosy; use furniture-transformers; make the colour palette should correspond to the age of the child; have interesting approaches to recreation areas (for example, the creation of "caves"); introduce wireless Internet; ensure availability of a school library, despite the use of all possible modern technologies; promote integration.

Analysing the design of the school environment of inclusive education institutions in foreign countries, authors suggest that a well-arranged classroom space inspires students to acquire knowledge actively, it 
creates a positive disposition and atmosphere. Modern educational space for children with mental retardation is based on a combination of the principles of flexibility (introduction of various forms of work) and stability (ensures continuity of process, manageability, order). There are two types of sources: stable (cabinets, teacher's desk, board) and mobile (desks, flip charts, ottomans, pillows, soft toys for hugging). It is the classroom furniture that should provide flexibility in the organisation of the educational environment. Centres should promote various forms of work, be practical, creative, colourful, balanced. The colour of the walls in primary school should correspond to warm colours (yellow, orange, red), in older - cold colours (blue, dark blue, grey, a combination of white and black) [16]. It is difficult to overestimate the importance of space upon forming the consciousness of a junior student with mental retardation because the first impressions and positive emotions from contemplation depend on the objective-spatial expediency, convenience, coherence, symmetry, harmony, and informativeness.

Analysing the problem of organising the educational space of primary school in different countries, authors identify the main terminology of the phenomenon, in our opinion, synonymous with the concept of educational space, namely: universal design for learning, spatial design, classroom layout, educational design, etc. [16]. Therefore, it is quite appropriate to introduce the concept of universal design in inclusive education into the practice of the New Ukrainian School at the legislative level. Its content and understanding includes: subject design, environmental design, design of curricula and services, which will ensure their use by all persons without special adaptations.

\section{DISCUSSION}

Inventory and logistics management - one of the most important conditions for the implementation of both the basic curriculum and various options for its adaptation in accordance with the special educational needs of children with mental retardation. Material and technical support of school education of students with mental retardation should meet not only general but also their special educational needs. In this regard, the structure of material and technical support of the educational process should reflect the specific requirements of the organisation of space where the child learns with mental retardation; organisation of temporary training regime; technical means of teaching students with mental retardation; special textbooks, workbooks, didactic materials, computer-based learning tools that meet the special educational needs of students with mental retardation and allow to implement the selected version of the curriculum.

Space (primarily the building and the surrounding area), where students with mental retardation are educated, must meet the general requirements for educational organisations, namely to comply with sanitary and hygienic standards of the educational process; to ensure sanitary and social and living conditions; to comply with fire and electrical safety; to comply with the requirements of labour protection; to the observance of timely terms and necessary volumes of current and capital repairs, etc.

The Ministry of Regional Development of Ukraine initiated the project "New Educational Space". The purpose is to renovate school buildings on the principles of manufacturability, motivational, and creative design, inclusiveness. In accordance with Order No. 283 of March 23, 2018 "On approval of the Guidelines for the organisation of the educational space of the New Ukrainian School", the spatialobjective environment, curricula, and teaching aids of students with mental retardation are changed. All this should promote the free development of the child's creative personality. Since the New Ukrainian School (NUS) offers project-team work, the question arises regarding the diversification of the organisation of educational space. The classroom should create such conditions to ensure high productivity of students with mental retardation, stable performance, maintaining the health of students, the use of new IT technologies, modern multimedia teaching aids, updating educational equipment [19].

All the above is implemented in the practice of Ukrainian schools through:

1. The place for educational and cognitive activities with appropriate furniture.

2. Variable theme-based place where boards, flip charts, stands, etc. are placed.

3. Game place, equipped with board games, equipment for mobile games.

4. Place for artistic and creative activities with shelves for storing accessories and a stand for a variable exhibition of children's works.

5. Wildlife corner 
6. Leisure place with carpet for sitting and playing, chairs, ottomans, cushions with a softcover.

7. Children's class library.

8. Teacher's office, equipped with a table, chair, computer, shelves, drawers, cabinets for storing didactic material, etc. [20].

These places are called differently. Thus, I. Yagupa distinguishes the centre of discoveries, news, materials, communicative, theme-based, the centre of silence and teaching. Authors propose to add to the areas mentioned above a place of achievement acknowledgement and a place of demonstration.

The first place. The Ministry of Education and Science recommends safe (with rounded edges), ergonomic, variously shaped (trapezoidal, triangle, etc., which ensures a quick transformation for group work), durable, not heavy (so that students with mental retardation can move them independently: chair weight $4 \mathrm{~kg}$, desks $10 \mathrm{~kg}$ ), of warm shades of yellow, green, blue, beige furniture in the classroom, which would have an attractive appearance, modern design and match the style of the general arrangement of the room. The Guidelines for the organisation of the educational space of the New Ukrainian School state that the educational space for children with mental retardation is organised in such a way that the teacher can observe the activities of children in all educational sources and children had the opportunity to move safely and have a place to store personal belongings [8].

A classroom is a place where students spend half a calendar year. Therefore, it should be interesting, orderly, easy to use, and relaxing. Classroom design is a creative process that lasts all year round and depends on the size of the classroom; the number of children who will study there, equipment; teacher creativity; parental assistance, etc. Classroom design should convey information about students and their teachers. That is why authors are impressed by the idea that a teaching centre, like American schools, should contain information about the teacher: photos from life, improvements, certificates, creative discoveries and much more that will allow parents and students to create the image of a teacher. The furniture in the classroom is placed in a way that children can move freely, but not run around the classroom. The Ministry of Education and Science advises not to make long straight paths through the entire class. The teacher must also move freely in the classroom, being able to approach all students or observe them. Students must get to the necessary didactic materials and boards without obstacles. There are several options for placing students in the classroom: 1 Option. Students sit separately from each other. Option 2 . Students sit in pairs. Option 3. Students sit in groups of 4 or 5 people. Option 4 . The desks in the classroom are placed in the form of a horseshoe. Each of these options has its pros and cons, depending on the purpose of the lesson.

The second place. The walls of the classroom also constitute an element of educational space. They should be painted in warm solid colours, without distracting bright patterns. Visual materials placed on them should complement the topics that children are currently studying. In addition, it is advisable to place variable "I-schemes" on the walls; student work; weather calendar; information about school projects indicating the tasks and role of each participant, news of the class, school, city; photo chronicle, etc. Another innovation that is offered for use in educational institutions is flip charts, which are modern mobile boards used during presentations, group events for a graphic image or explanation of basic ideas. They usually come with a metal surface on a tripod, have an aluminium frame, a shelf for accessories, a fixed paper holder, adjustable height. In some flip charts, the support may be on wheels. Flip charts are very easy to use: they can be moved from place to place, and if they are not needed, they can be folded and hidden behind a closet. With their help, the teacher speaks to the students and at the same time, sketches or writes something down. If there is a need to return to this material, the sheet of paper can be reattached to this portable board. With the help of a presentation board, students learn to speak in front of an audience, to speak their own thoughts aloud, to record them by graphic depiction. Currently, such boards are in demand among employees of various organisations and offices during various presentations. Therefore, the ability to work with them will be useful in the future. It will also be advisable to place the so-called "author's chair". One can use a regular student chair. It can be used both during morning meetings and during students' answers in class. It allows students with mental retardation to develop leadership qualities.

The third place is for play because play activities remain an important activity of the child with mental retardation. The agreement between the Ministry of Education and Science and Lego is noteworthy. As is 
known, the company has signed a memorandum with the Ministry, according to which it provides first-graders with sets of "6 bricks" and sets of "LEGO Play Box". In addition, Dienes blocks, Kuizener sticks, modern board games such as "Reader", "33 and 3 beavers", "Bilchin's warehouse", etc. should be placed in the centre.

The fourth place for artistic and creative activities of students with mental retardation can be a four-sided cabinet that contains enough educational sources, boxes, and drawers for storing materials for children's artistic and creative activities. An art place may contain materials to study a specific topic (for example, if children are studying the topic "World Oceans" magazines with illustrations of oceans, sand, shells, salt and other objects that can be found by the ocean) - children will love using them to make various works of art; sponges, brushes, and spray bottles for painting; reproductions of famous paintings.

The fifth place. A wildlife area is a place where plants are grown, animals are cared for, and observations and experiments are performed, many of which are provided for in the environmental studies curriculum. Unfortunately, in the analysed foreign schools' authors did not find such a zone, although authors believe that it adds comfort and cosiness allows to form such positive personality traits as responsibility, diligence, neatness, emotionality, aesthetic vision of the world, love of all living things, observation, etc. The care for natural objects also forms a careful attitude towards nature, promotes ecological, aesthetic, and labour education. Ideally, an entire room should be designated for a corner of wildlife. In the classroom, one can find a comfortable place that should be well lit, meet the standards of animal husbandry and plant breeding. Most often school allocate a shelf in the classroom for this purpose, use a special curbstone or window sills. The easiest way to grow flowering plants: asparagus, aloe, araucaria, begonia, balsam, coleus, various species of cacti, fuchsia, Uzamba violet, sansevera, tradescantia.

Among the representatives of the animal world are common protozoa, intestinal, molluscs, arthropods, fish, amphibians, reptiles, birds, and small mammals. The teacher must be responsible for the selection of the inhabitants of the classroom of nature. In the authors' opinion, it is most expedient to choose undemanding, safe representatives of the animal world that live in the aquatic environment or terrariums. Authors believe that it is impractical to start many animals. The teacher must realise that a certain amount of work to care for the residents of the corner will fall on their shoulders. Authors would not recommend breeding birds, which by their singing can distract students from the perception of educational material. It is also very often necessary to clean after the rodents, so as not to spread an unpleasant odour in the classroom. In the authors' opinion, the most suitable inhabitants of the wildlife area will be aquarium fish, snails, protozoa, and molluscs. Authors advise starting an ant farm. It is innovative, interesting, without unnecessary hassles.

The sixth place for recreation. In the classroom for younger students with mental retardation, it is desirable to designate a place where a carpet can be laid. On the carpet, children together with the teacher can sit in a circle for communicative moments, rest, reflect on themselves, or perform certain tasks. Thus, morning meetings can be held on the carpet to tune in to work further. Morning school meetings are an interesting and important method of work for primary school teachers. It will unite children, create a single community, and form a sense of community in younger students, improve the relationship between children and between children and teachers. Of course, such activities will require time, attention, patience, creativity, and emotional expenditure of teachers. Effective community building will depend on the style of pedagogical leadership chosen by the teacher. This process is incompatible with the strict control of the teacher because then it will not be possible to create an atmosphere of openness and ease. In this way, the teacher will be capable of instilling in children the skills and abilities of effective communication and active listening.

Such a furniture attribute as a bean bag deserves special attention. This thing is easy to transport, inexpensive, and ergonomic. At the same time, it can be extremely useful in the recreation area of the primary school classroom, because it is still difficult for younger students to spend so much time at the desk. Therefore, it will be useful for them to take a semirelaxed position and feel themselves and their body. In the practice of some pilot schools for the implementation of the concept of the NUS, authors point at such a phenomenon as "Hugger" - a large soft toy for children, which can be hugged.

The seventh place - children's classroom library in the form of open cabinets or shelves. For convenience, it is advisable to allocate a department in the classroom library for methodological literature and didactic 
materials for books and subjects that can be used in conducting lessons, and for interesting children's literature. The teacher must consider the age characteristics of younger students: literature in the classroom library should be designed for the age of children, contain accessible material and interesting illustrations. Thus, the student will be able to choose a book that interests them. And if the book is small in volume and can be read in 10-15 minutes, then the student will return the book to its place on the shelf without reminders. One should also consider the height of cabinets and shelves so that interesting literature is easily accessible. A classroom library will benefit from visuals or dummies for some of the lesson topics. And they should not be hidden, because children are interested in closer examination and study of these things by touch. This usually only applies to safe objects.

The eighth place - teacher's zone. This is the teacher's personal, professional space. It should be organised so that it is convenient to carry out professional activities, and at the same time plan, evaluate, reflect, and complete their activities. Space should be convenient for individual conversations with students, and it should enhance the educational impact. Space may include a teacher's desk, chair, computer, shelves, cabinets for storing study or handouts, etc. An important requirement for organising the teacher's area is a convenient location because all places should be in the teacher's field of vision. Also, the organisation of the teacher's place is a kind of selfexpression, which will allow showing personal tastes, teacher preferences, their professional credo.

\section{CONCLUSIONS}

Creating special educational conditions is the key to successful inclusion of a student with mental retardation in school life. The process of creating special conditions involves identifying (and, where possible, removing) the main barriers that a student may face when coming to school. The school begins with the organisation of new educational space as a carrier of symbolic information, which provides additional opportunities for the cognitive, aesthetic, ethical development of the subjects of the educational process. The ideas of organising the educational space of foreign countries, with a clear division into the physical environment, curriculum, human factors, are embodied in the practice of the NUS, so as to organise opportunities to meet the needs of the educational process while having its own features: by means of subjective-spatial environment and design; positioning of primary school as a centre of creativity and cooperation between students, teachers, parents, community.

Proper organisation of the educational space of the school will minimise feelings of insecurity among younger students, will allow free movement and security and will positively affect the development of social interrelations in the team. The educational organisation must have separate specially equipped rooms for classes with a teacher-defectologist, psychologist, teacher-speech therapist and other specialists who meet the objectives of the curriculum of correctional work and the tasks of psychological and pedagogical support of the students with mental retardation.

\section{REFERENCES}

[1] Harkovych OL. Principles of organisation of the educational environment during the study of chemistry. Bulletin of Chernihiv National Pedagogical University named after T.H. Shevchenko 2015; 120: 44-46.

[2] Hnatyuk LR. Features of shaping the environment of educational institutions. Theory and Practice of Design 2013; 3: 23-30. https://doi.org/10.18372/2415-8151.3.6204

[3] Kovileva YE. Construction of the educational environment of the modern school. In: Actual tasks of pedagogy: materials of the Vth International scientific conference reading. Chita: Young Scientist Publishing House 2014; pp. 117-119.

[4] Svitlichna VV, Chistilina TO. Educational space in the context of globalisation: paradigmatic pluralism and prospects for integration. Humanities Magazine 2013; 2: 83-92.

[5] Tsymbalaru AD. Pedagogical design of educational space in the school of the first degree: theory and practice: monograph. Kyiv: Pedahohichna dumka, 2013.

[6] Tsymbalaru AD. Trends in modeling the educational space in the context of the development of primary education in foreign countries. Pedagogical Education: Theory and Practice 2015; 18: 439-46.

[7] Yaroshynska O. Formation of the educational environment of the educational institution in the pedagogy of VO Sukhomlinsky. In: Vasyl Sukhomlynskyi and the school of the XXI century: tradition and innovation: Proceedings of the AllUkrainian scientific conference. Uman: PE Zhovtyy OO, 2012; pp. 82-85.

[8] Koehler MJ, Mishra P. What is technological pedagogical content knowledge? Contemporary Issues in Technology and Teacher Education 2009; 9(1): 60-70.

[9] Yagupa I. Adaptation-game cycle of primary education: features of the organisation of students' activities. Primary School Teacher 2018; 3: 28-31.

[10] Mashkina L. Jean-Ovid Decroly's pedagogical system. Pedagogical Discourse 2014; 16: 119-24.

[11] Vittra School Telefonplan. Retrieved from: https://rosanbosch.dk/en/project/vittra-school-telefonplan.

[12] Pasi Sahlberg. Finnish Lessons. What Can the World Learn from Educational Change in Finland? Retrieved from: https://www.amazon.com/Finnish-Lessons-2-0-EducationalFinland-ebook/dp/B00SZ7L8M4. 
[13] Pisarevsky M. Education in Finland: schools without walls, studies without grades. House of Innovation 2017. Retrieved from: https://innovationhouse.org.ua/ru/statti/.

[14] Elite private school in Switzerland - Institut Monte Rosa. Retrieved from: http://ru.globalstudygroup.com/1/10/839/ yelitnaya-chastnaya-shkola-v-shveycarii-institut-monte-rosa

[15] The most. The most. The most. Finland. The most persistent. Retrieved from: https://www.youtube.com/watch?v= uFkMR8mG6oc.

[16] Coloring the Classroom. SCHOOL Planning \& Management. Retrieved from: https://webspm.com/Articles/2013/12/01/ Coloring-the-Classroom.aspx.

[17] Flipchart. Retrieved from: https://web.archive.org/web/ 20100903095405/http://www.usingflipcharts.co.uk/.
[18] The education system in the United States. Retrieved from: https://www.eduget.com/news/sistema_osviti_v_ssha-239

[19] Order of the Ministry of Education and Science of Ukraine No. 283 "About the statement of Methodical recommendations concerning the organisation of educational space of New Ukrainian school" 2018. Retrieved form: https://mon.gov.ua/ua/npa/pro-zatverdzhennya-metodichnihrekomendacij-shodo-organizaciyi-osvitnogo-prostoru-novoyiukrayinskoyi-shkoli.

[20] Law of Ukraine No. 2145-VIII "On Education" 2017. Retrieved from: https://zakon.rada.gov.ua/laws/show/214519

Received on 05-08-2020

DOI: https://doi.org/10.6000/2292-2598.2020.08.03.2

(C) 2020 Bilousova et al.; Licensee Lifescience Global.

This is an open access article licensed under the terms of the Creative Commons Attribution Non-Commercial License (http://creativecommons.org/licenses/by-nc/3.0/) which permits unrestricted, non-commercial use, distribution and reproduction in any medium, provided the work is properly cited. 